\title{
The Divergent Paths of Iowa Quakers in the Nineteenth Century
}

\author{
THOMAS D. HAMM
}

A VISITOR to certain parts of Iowa in 1865 would have been struck by the seeming ubiquity of members of the Society of Friends, or Quakers. They were a relatively small part of the state's total population, perhaps nine thousand out of a total of about one million. But the tendency of Friends to cluster in communities around their meetinghouses and burying grounds meant that they were thickly settled in certain places. Henry and Keokuk Counties in southeast Iowa, for example, had large Quaker populations, while other counties, such as Dubuque or even nearby Des Moines, had virtually none. ${ }^{1}$

Friends stood out from their neighbors because of the "peculiarities" that they imposed on themselves. Such practices were designed very consciously to separate them from "the world." Quaker dress, with its broad-brimmed hats and collarless coats for the men and round-backed, unornamented bonnets for the women, was one. The Quaker plain language-using "thee" and "thy" instead of "you" and "your," and eschewing the pagan names of the months of the year and days of the week in favor of numbers (thus Sunday was First Day, January First Month, and so on)-was another. Friends gathered in utterly plain, unornamented buildings they called meetinghouses, without altars or communion tables. They worshiped in silence, without pastors or music, men seated on one side of the room, women

1. See the map of meetings in Iowa Yearly Meeting of Friends, Minutes, 1870; and U.S. Department of Commerce, Historical Statistics of the United States: Colonial Times to 1970, 2 vols. (Washington, DC: Bureau of the Census, 1970), 1:27.

THE ANNALS OF IOWA 61 (Spring 2002). (C) The State Historical Society of Iowa, 2002. 
on the other, confident that if God had a message for the assembled congregation, someone would be moved to share it. The Civil War brought another Quaker peculiarity to the fore: Friends believed that all wars and fighting were wrong, and so urged members not to serve in the Union army, even as Friends resolutely opposed slavery and almost as a body supported the Lincoln administration and its efforts to preserve the Union. ${ }^{2}$

These outward similarities, however, masked deep fissures and differences. Iowa Friends were divided into three different groups: Gurneyite, Wilburite, and Hicksite. Their disagreements, abstruse in the eyes of outsiders, involved vital points for each body. A generation later, the divisions would be even greater. By then, most Iowa Quakers identified themselves as part of the "Friends Church" and had cast off most of the outward peculiarities that once marked them. By doing so, this majority starkly distinguished themselves from those who held to older ways.

In many ways, Iowa in the last third of the nineteenth century was a Quaker microcosm, mirroring divisions that split Friends from New England to the Pacific Coast. The differences usually had their origins elsewhere, but Quaker migration brought them to Iowa. Some Iowa Friends, particularly the small and isolated communities of Hicksite Friends, were marginal to the main tendencies within their larger bodies. Others, Conservative separatists, would be important forces in creating a new branch of American Quakerism. Most vital to the course of American Quakerism, however, would be the revivalist, pastoral Iowa Yearly Meeting that emerged from revolutionary changes in the 1870 s and 1880 s. Numbering four times the membership of all other Iowa Friends combined, it would be a major force in the creation of a new vision of American Quakerism, one that a majority of American Friends embraced. But that new vision, while attracting new members and giving what many Friends thought was badly needed new life, was so radically different from past Quaker practice that many could not accept it. In the 1880 s and 1890 s, moreover, it led to controversy over

2. See Thomas D. Hamm, The Transformation of American Quakerism: Orthodox Friends, 1800-1907 (Bloomington, IN, 1988), 1-11, 66-69. Some Friends did depart from Quaker tradition and serve in the Union army during the Civil War. See ibid., 66-68. 
the ministry of an Iowa Yearly Meeting Gurneyite minister, Joel Bean, and became the center of the Quaker equivalent of a heresy trial, one that would have international repercussions. That case was unlike virtually all others in that Bean's "heresy" lay in his resistance to innovations. Before 1870 , Iowa Friends had been both intellectually and geographically on the periphery of the Quaker world, growing in numbers but reacting to trends and movements that began elsewhere. After 1870, Iowa Friends, taking the lead in innovations such as the pastoral system, became central to world Quakerism.

This story has been largely unexplored. The last scholarly history of Iowa Quakerism was published in 1914. The yearly meetings have published histories to mark events such as centennials, and Iowa historians have explored certain aspects of Quaker history, such as the establishment of Scattergood School by Conservative Friends. Historians exploring other aspects of American Quaker history have also dealt with Iowa, focusing on the important role it played in the late nineteenth century. Yet, to date, no one has attempted to pull together the various strands of Iowa Quakerism and show how the paths of Iowa Quakers came to diverge so dramatically after the Civil War. ${ }^{3}$

QUAKERS first came to Iowa in 1835, when Isaac Pidgeon, a Friend from North Carolina who had moved to Illinois in 1831, crossed the Mississippi to explore west of the river. Word soon spread of the fertile lands there, and other Quaker families, mainly from Indiana, followed. By October 1838, enough Friends were living in the vicinity of Salem in Henry County to earn the right to hold their own monthly meeting, the basic Quaker unit for business purposes. From the first settlement at

3. The standard history of Iowa Quakerism in the nineteenth century is Louis Thomas Jones, The Quakers of Iowa (Iowa City, 1914). A well-illustrated but brief historical account is Iowa Yearly Meeting of Friends, 1863-1963: Spiritual Trails of a People Called Friends (n.p., 1963). Considerable material on Conservative Friends in Iowa appears in Robert Berquist et al., Scattergood Friends School, 1890-1990 (West Branch, 1990). For treatments of Iowa Quakers in general histories of Quakerism, see Rufus M. Jones, The Later Periods of Quakerism, 2 vols. (London, 1921), 2:840-41, 900-902; Elbert Russell, The History of Quakerism (New York, 1942), 421-34, 482-98; and Hugh Barbour and J. William Frost, The Quakers (Westport, CT, 1988), 203-15. 


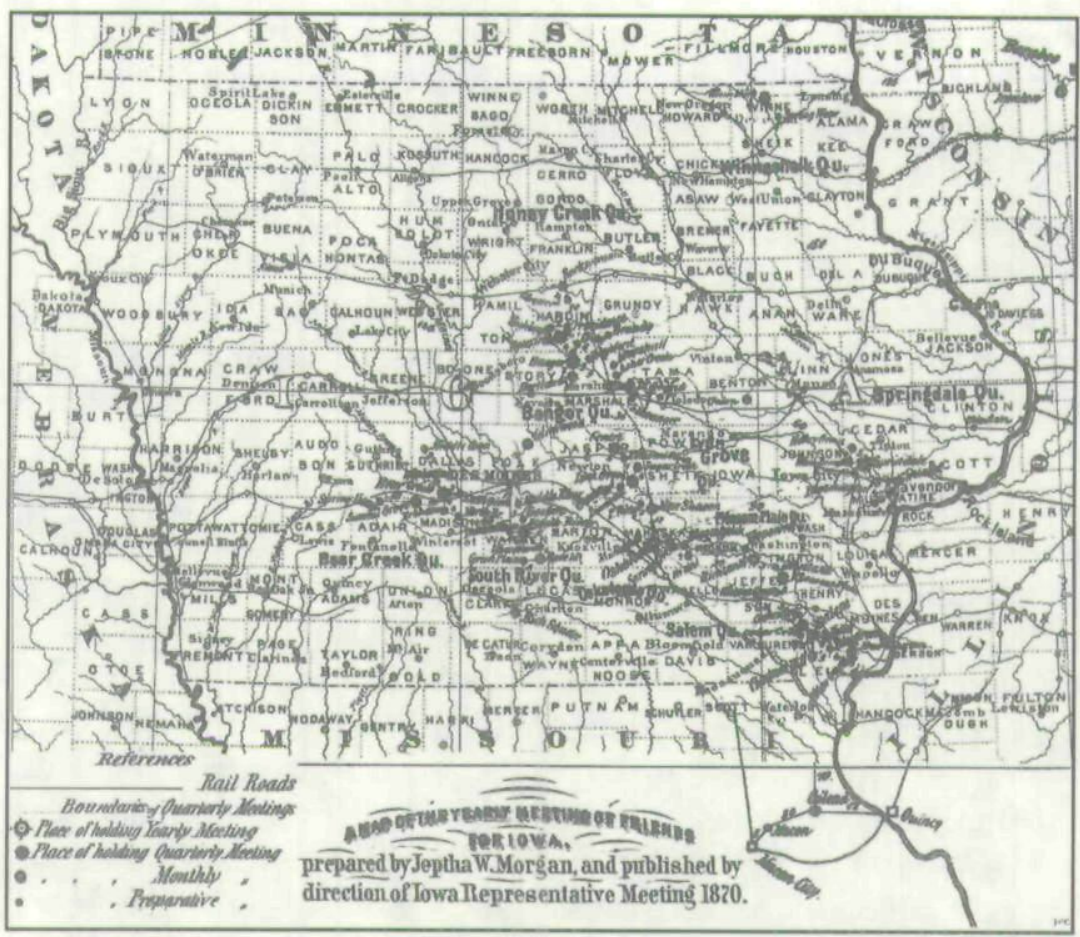

SOURCE: Iowa Yearly Meeting of Friends, Minutes, 1870.

Salem, Quakerism spread north and west in Iowa. By the late 1850s, Friends in Indiana Yearly Meeting, of which Iowa Friends were a part, were already looking to the time when Iowa Friends would be "set off" in their own yearly meeting. That came in 1863, with the formation of Iowa Yearly Meeting.

4. Jones, Quakers of Iowa, 38-73. Friends use the term meeting to denote both an event and an institution. The lowest level of Quaker organization was the local congregation, usually referred to as a preparative meeting, or simply as a meeting. One or more preparative meetings made up a monthly meeting, the basic unit of Quaker governance, which received and disowned members, solemnized marriages, and held property. Two or more monthly meetings made up a quarterly meeting, charged with handling business that was beyond the purview of the monthly meeting. The highest level of Quaker organization was the yearly meeting. It handled appeals of disciplinary cases and was the final authority for matters of faith and practice. Yearly meetings did not coincide with state lines. Indiana Yearly Meeting, for example, in 1850 stretched from central Ohio to west of the Mississippi. When Iowa Yearly Meeting was formed, it included Friends in Minnesota and Wisconsin as well. See Hamm, Transformation, xvi. 
These new Quaker communities shared a doctrinal and theological outlook before 1850 . They were made up of Orthodox Friends, the larger group that emerged from the greatest split American Quakerism would ever experience, the Hicksite Separation of 1827-1828. That separation began in Philadelphia Yearly Meeting, pitting supporters of the Long Island Quaker minister Elias Hicks (1748-1830) against opponents who accused Hicks of dangerously heterodox views on the authority of Scripture and the divinity of Christ. Hicks's supporters, who became known as Hicksites, responded that their views were in accord with primitive Quakerism and that the Orthodox had been overly influenced by non-Quaker evangelicals with whom they were forming ties in various reform and humanitarian organizations. ${ }^{5}$

The first lasting rupture in the fabric of Iowa Quakerism was the result of another separation in the East. Between 1830 and 1850, most Orthodox Friends in the United States moved in an increasingly evangelical direction. They organized Sunday schools, or what were called at the time First Day schools; joined non-Quaker evangelicals in a variety of reform and humanitarian projects, such as temperance; and spoke increasingly in terms of the necessity of an instantaneous conversion experience, a vision of the nature of religious life that marked a break with earlier practice. Such Friends took much of their inspiration from the well-known English Quaker minister Joseph John Gurney, who traveled extensively in the United States from 1837 to 1840 (although he did not visit Iowa). Some very conservative Orthodox Friends saw this new tendency as a break with historic Quakerism and criticized it bitterly. They found their bestknown leader in a Rhode Island Quaker minister, John Wilbur. Those sympathetic to Wilbur were labeled, in Quaker circles,

5. Hamm, Transformation, 15-20; H. Larry Ingle, Quakers in Conflict: The Hicksite Reformation (Knoxville, TN, 1986); Jones, Quakers of Iowa, 133-45. Hicksites were a majority in the eastern yearly meetings of Friends where separations took place, but were probably less than half of Friends in Ohio Yearly Meeting, and only about a sixth of the members of Indiana Yearly Meeting. Although Friends did not have pastoral ministers or a clerical class, they did acknowledge that certain members had a gift for speaking in meetings for worship and recognized that gift by recording it-thus the Quaker title of "recorded minister." See, for example, Hamm, Transformation, 8. 
Wilburites. The larger body of more evangelical Orthodox Friends became known as Gurneyites. ${ }^{6}$

Some Wilburite Friends eventually made their home in Iowa. Their presence caused a small separation among Iowa Quakers in the $1850 \mathrm{~s}$. More important was the migration of Wilburite Friends from eastern Ohio, a Wilburite stronghold, between 1855 and 1865 . By 1864 there were three monthly meetings: Coal Creek in Keokuk County, Whittier in Linn County, and Hickory Grove in Cedar County. Those three meetings organized the Hickory Grove Quarterly Meeting. They eschewed ties with all other Iowa Friends, questioning their legitimacy. In 1890 the Wilburite Friends founded Scattergood Friends Boarding School near West Branch in order to educate Quaker children without compromising any of the traditional peculiarities. They prided themselves on their resistance to change. As Louis Jones noted in his history of Iowa Quakerism in 1914, "in almost every particular and to the minutest detail they have succeeded in preserving the peculiarities, not to say the eccentricities, of Quakerism as it appeared three-quarters of a century ago." Well into the twentieth century they continued to use, with only minor revisions, the Discipline that Ohio Yearly Meeting had adopted in 1819.7

The Wilburite Friends were not the only Quakers in Iowa who held to traditional ways of silent and unprogrammed worship into the twentieth century. In the 1840s, a few Hicksites, mainly from eastern Ohio, crossed the Mississippi into Iowa. They were isolated from other Hicksites, however, and it was not until 1855 and 1856 that Hicksite Friends from Virginia arrived in Iowa in such numbers as to form their own communities and meetings. ${ }^{8}$

The Iowa Hicksites were probably at their zenith in the 1870 s. They were relatively few in numbers, but they did have one gifted minister and leader, Joseph A. Dugdale, who settled in Mount Pleasant in 1862. A native of New Jersey, he had moved

6. Hamm, Transformation, 20-35.

7. Jones, Quakers of Iowa, 159; Frank Luther Mott, Time Enough: Essays in Autobiography (Chapel Hill, 1962), 5-19; Berquist et al., Scattergood Friends School, 4-14. 8. Jones, Quakers of Iowa, 147-48; "A Memorial concerning John Wright, an Elder of Wapsaenonoc Monthly Meeting," Friends' Intelligencer, 31 December 1870, 694; Baltimore Yearly Meeting (Hicksite), Minutes, 1865, 19-23. 


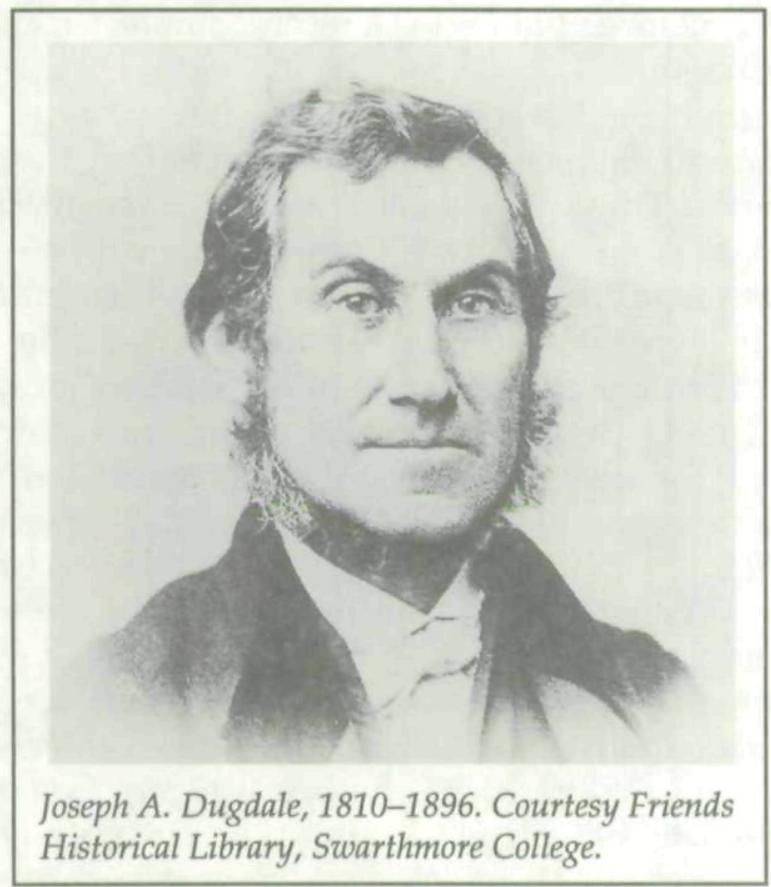

to Ohio as a young man, where he was recorded a Friends minister. Dugdale threw himself into the radical abolitionist movement against slavery with passion in the 1830 s, serving as a conductor on the Underground Railroad. In 1843 he led a secession from the Hicksite Indiana Yearly Meeting, which looked on membership in antislavery societies that included non-Quakers as dangerous. With sympathizers, Dugdale formed the Green Plain Yearly Meeting of Congregational Friends, perhaps the most radical reformist group in the Ohio Valley. The Green Plain Friends called for disbanding the army and navy; advocated woman suffrage and complete equality for African Americans; and even discontinued formal membership in their meetings as a dangerous infringement on individual liberty. Dugdale was their acknowledged leader. By the time he moved to Mount Pleasant in Henry County, Iowa, in 1862 , the issues that had given rise to the earlier schisms had faded away. Dugdale applied for membership at the Hicksite Prairie Grove Monthly Meeting and was immediately received, 
not just as a member, but also as a recorded minister, an unprecedented concession. ${ }^{9}$

After arriving in Iowa, Dugdale threw himself into a plethora of reform and religious activities. Woman suffrage was a particular interest. Dugdale had been one of the organizers of the first National Woman Suffrage Convention, held in Worcester, Massachusetts, in 1850, along with such noted feminists as Lucretia Mott (a personal friend), and Elizabeth Cady Stanton. Dugdale, his wife, Ruth, and his mother, Sarah, who was also a minister, all had extensive personal acquaintance and experience with leading figures in the women's rights movement, many of whom thus stopped in Mount Pleasant on their speaking and organizing tours. In June 1870 Dugdale took the lead in calling a convention in Mount Pleasant that formed the Iowa Woman Suffrage Association. ${ }^{10}$

Dugdale also visited widely among Friends meetings in Iowa, Orthodox as well as Hicksite. There is no evidence that he was admitted to Wilburite meetings, but Henry County was a major Gurneyite center, and a Virginia Hicksite visiting Iowa in 1864 wrote home that Dugdale was "a great favourite among Friends of both meetings." Dugdale wrote that he had received "much courtesy and kindness" from the Gurneyites, and they said that "notwithstanding he is associated with another branch of Friends he has been welcomed repeatedly to our platform

9. Samuel M. Janney to John Janney Jr., 31 May 1851, box 3, Samuel M. Janney Papers, Friends Historical Library, Swarthmore College, Swarthmore, PA; John J. White, "Divisions among Friends," Journal [Lancaster, PA], 5 February 1879, 22; Thomas D. Hamm, God's Government Begun: The Society for Universal Inquiry and Reform, 1842-1846 (Bloomington, IN, 1995), 217; Albert John Wahl, "The Congregational or Progressive Friends in the Pre-Civil-War Reform Movement" (Ed.D. diss., Temple University, 1951), 45-53; Joseph A. Dugdale, "PencilingsNo. 6," Journal, 3 December 1873, 347; "Joseph A. Dugdale and the Friend Quakers," ibid., 5 January 1876, 395. When a "weighty" visiting Friend cautioned the monthly meeting about receiving someone as a member and recording him a minister simultaneously, Dugdale himself urged Friends to wait. So he was formally recorded as a minister at the next monthly meeting. See Memoirs of Samuel M. Janney, Late of Lincoln, Loudoun County, Va. (Philadelphia, 1881), 210.

10. Louise R. Noun, Strong-Minded Women: The Emergence of the Woman-Suffrage Movement in Iowa (Ames, 1969), 133-35; Henry Miles Letter, Journal, 29 March 1876, 75; Lucretia Mott to Mary Post, 14 March 1865, Post Family Papers, Friends Historical Library. 
and to the meetings in our Society." In some meetings he was placed on the facing benches at the front of the building with the elders and ministers, an unprecedented honor for a Hicksite Friend among the Orthodox."

After 1880, however, Dugdale's health declined, and Iowa Hicksites found no one to take his place. Some meetings found themselves divided by disputes whose sources are now obscure. "The outlook for the future of our meetings in this state has often appeared exceedingly unpromising," wrote Thomas D. Tomlinson of Marietta in 1882. Thomas E. Hogue, a Hicksite from Webster City, agreed. "I have often looked over the field which our Society in this western land presents-and to me the view is not by any means a hopeful one," he wrote. At Highland in 1892, it was perhaps a sign of the prevailing pessimism that a First Day school convention discussed the question: "Is the Mission of the Society of Friends finished?" Between 1870 and 1891, the number of Hicksites in the state fell from 424 to $355 .^{12}$

Still, committed Hicksite Friends in Iowa wanted to persevere. In an attempt to strengthen struggling meetings, they encouraged ministers from other states to visit. They saw themselves as still having a mission: keeping alive principles that they thought were basic to Christianity. "We Friends-or those who really are Friends - feel when we enter our meetings for divine worship though not a word be spoken-held as they are often in profound silence- that they are seasons of real comfort - seasons of sweet baptism of the Holy Spirit." To keep this experience alive, Hicksite Friends in Iowa continued to struggle in the face of discouragement. ${ }^{13}$

11. Joseph A. Dugdale to Samuel M. Janney, 15 January 1870, box 5, Janney Papers; Samuel M. Janney to Elizabeth Janney, 18 May 1864, box 4, ibid.; "An Interesting Discourse," Journal, 17 September 1873, 259; Joseph A. Dugdale, "Pencilings-No. 21," ibid., 15 September 1875, 266; "Friends and Methodists in Chicago," ibid., 20 October 1875, 309; White, "Divisions among Friends," 22.

12. Thomas E. Hogue to Abel Mills, 2 July 1890, 25 February 1893, 6 February 1894, 23 February 1899, box 1, Abel Mills Papers, Illinois Historical Survey, University of Illinois Library, Urbana, IL; Emmaline M. Underhill to Abel Mills, 18 May 1885, ibid.; "Correspondence," Friends' Intelligencer, 18 February 1882, 6; "News of Friends," ibid., 21 November 1891, 746; "From Highland, Iowa," ibid., 16 July 1892, 458.

13. T. E. Hogue, Paper: The Inner Light: Presented to and Read Before the Illinois Yearly Meeting of Friends Held at Clear Creek, Illinois, Ninth Month, 1892 (n.p., 
Events taking place among the largest body of Iowa Friends, the Gurneyites, may have reinforced the Hicksites' sense of mission. By 1900, the gap between the Gurneyites and the other bodies of Iowa Friends had widened into a chasm that remains to this day. Gurneyite Friends had decided that their growth and survival depended on embracing significant change.

Apparently, the ferocious rhetoric and feelings of the 1820s, when Orthodox Friends charged Hicksites with being infidels and allies of the Antichrist, and Hicksites attacked Orthodox Friends as tyrannical and oppressive, were almost entirely absent from relations between Gurneyites and Hicksites in Iowa before 1870. Hicksites liked to tell the story of two elderly women Friends who met in an Iowa village, previously unaware that there was any other Quaker in the area. They began to meet together for worship. Two years passed before they realized that one was Hicksite and the other Orthodox. Joseph Dugdale's invitations to attend and speak in Gurneyite meetings is additional evidence of amicable relations between the groups. And in 1873, when Hicksites near New Sharon wanted to hold a meeting, Gurneyites there cheerfully made their meetinghouse available. A Hicksite Friend wrote, "I see in the vision of light that in a future day .... there will be a more close uniting of the several branches of the Society of Friends. Extremists on either side may not coalesce, but the solid masses will." At least some Gurneyite Friends agreed. Joel Bean, the clerk of the Gurneyite yearly meeting, told Dugdale that the two groups were not "radically opposed in fundamental doctrine." Another Gurneyite was more definite. "What a pity it is we are divided. We ought all to be one body," he told Dugdale. ${ }^{14}$

That would not be the direction Iowa Gurneyite Friends took, however. Instead, in the 1870s, they found themselves un-

n.d.), 1-4; T. E. Hogue to Abel Mills, 2 July 1890, 24 March 1892, box 1, Mills Papers; "Friends at Webster City," Friends' Intelligencer, 16 July 1892, 458; T.E.H., "The 'Western Department's' Experience," ibid., 30 July 1892, 500-501.

14. "Establishment of a New Quarterly Meeting in the State of Iowa," Friends' Intelligencer, 30 June 1866, 261; "Communicated," Journal, 23 June 1875, 170; "Friends in Iowa," ibid., 4 February 1873, 10; Joseph A. Dugdale, "Pencilings -No. 3," ibid., 8 October 1873, 283; Joseph A. Dugdale, "Pencilings-No. 28," ibid., 29 March 1876; Joseph A. Dugdale, "Pencilings-No. 23," ibid., 20 October 1875, 306-7; Borden Stanton, "Western Friends," ibid., 14 January 1873, 2. 
dergoing nothing short of a revolution. They laid aside most of their traditional peculiarities and embraced a revivalism that drew largely on non-Quaker sources. Not only did this widen the gap between them and the Wilburite and Hicksite bodies, but it also led to a new round of separations, as Gurneyite Friends who could not tolerate the innovations departed.

BETWEEN 1830 AND 1860 most Gurneyite Friends in the United States moved closer to the nation's larger evangelical culture. Before 1830, Quakers saw religious life largely in terms of growth. They did not speak of achieving salvation through a single experience of being "born again," or converted, as did other evangelical Protestants. Instead, Friends saw the achievement of salvation as a long, gradual process. Through separation from "the world," and obedience to the leadings of the Inner Light, one was gradually purged of evil and desire to sin. Thus the end product would be a state of holiness or sanctification, which Friends saw as necessary to achieving salvation. ${ }^{15}$

Between 1830 and 1860, Gurneyite Friends, led by Joseph John Gurney himself, modified this understanding in fundamental ways. Increasingly, they, like other evangelical Protestants, came to see religion as beginning with an instantaneous, definite conversion experience. That experience was achieved through simple faith in the efficacy of the Atonement of Christ. Thereafter would follow a period of gradual growth into holiness, which Gurneyites now made a separate experience, distinct from conversion. Although even to some historians this seems an abstruse point, it was vital for Friends. One of John Wilbur's chief criticisms of Gurney was on this very issue. Hicksites, of course, saw it as simply another instance of the Orthodox being overly influenced by outsiders. ${ }^{16}$

This new vision was reinforced by much of the preaching that Friends heard and the books and periodicals that they read.

\section{Hamm, Transformation, 1-11.}

16. Ibid., 12-35. For the impact of Joseph John Gurney on Quakerism, see Jones, Later Periods, 1:492-540; Elizabeth Isichei, Victorian Quakers (Oxford, 1970), 3-16; and David E. Swift, Joseph John Gurney: Banker, Reformer, and Quaker (Middletown, CT, 1962). 
It was a staple, for example, in the Philadelphia-based Friends' Review, the most widely read periodical among Iowa Friends. It was also reinforced by the introduction of Sunday schools, or "First Day Schools for Scriptural Instruction," as they were called at the time, which by the 1860 s had become an integral part of the life of Gurneyite Friends in Iowa. "It seams so nice to be there and here the Scripters explaned," a Friend in Lee County wrote to a cousin back in Indiana in 1862 . "I want thee to pray for its increase that we may do some good." Other Gurneyites set up Sabbath schools for non-Quaker children. In 1865 young Friends at the Center Grove Academy near Oskaloosa organized a "Christian Vigilance Band" to evangelize and gain converts. That same year Iowa Yearly Meeting told its members bluntly: "Ye must be born again.."17

Representative of the new religious approach of Iowa Friends was Joel Bean, a New Englander who settled at West Branch in 1854 and was recorded a minister in 1858. In that year he wrote in his journal that "the Gospel which seems given to me to declare is the love of God in our Lord Jesus Christ - the glorious plan of redemption and regeneration thro' a Saviour." In 1861 Bean and his wife, Hannah, made an eight-month tour of the Hawaiian Islands, preaching in the churches of other denominations and winning praise from their clergy. Joel wrote to the Friends' Review that the time had come for Friends to send missionaries out to other lands to win heathen souls for Christ, as other denominations did. Hannah Bean was even attracted to the preaching of Dwight L. Moody, probably the most influential evangelical revivalist in the United States after $1860 .^{18}$

Iowa's Gurneyite Friends were not alone in this movement toward the dominant evangelical culture of the United States. Rather, it was characteristic of Gurneyite Friends generally in the 1850 s and 1860s. They perceived that Quakerism had become stultified and ossified, overly concerned with preserving peculi-

17. Jones, Quakers of Iowa, 97-98; Elizabeth Bond to Jehiel Bond, 13 May 1862, box 1, Bond Family Papers, Illinois Historical Survey; Iowa Yearly Meeting of Friends, Discipline (Chicago, 1865), 38-39; John Y. Hoover, History of the Life and Labors of J. Y. Hoover (n.p., 1909), 42.

18. Thomas D. Hamm, "Joel Bean and the Revival in Iowa," Quaker History 76 (1987), 38-39. 
arities and traditions. For many young Friends, Quaker doctrines such as unprogrammed worship, the equality of men and women, and pacifism were vital. But they saw other peculiarities, such as disownment for marriage to non-Friends, as both unnecessary and harmful. Esther Frame, who joined Friends at Salem in 1866, later wrote that she had been the first person to request membership there in twenty years. That was not true, but the fact that Frame believed it, and that others believed her claim, shows how widespread the perception was that Friends were not interested in evangelizing and attracting others to Christ. So a new generation of leaders began to push for change. Iowa Friends were not at the forefront of the movement, but many of their leaders, such as the Beans, Elwood Osborn, and Lindley M. Hoag, had ties to its leaders in other yearly meetings. Joel Bean, for example, had been a student at the Haverford Friends School with Timothy Nicholson and Dougan Clark Jr., who led the movement in Indiana; and Hannah Bean was a member of the Shipley family, leaders of the movement in Philadelphia. ${ }^{19}$

By 1860, Gurneyite Friends had become numerous enough in Iowa to form their own yearly meeting. It held its first sessions in September 1863. The establishment of a yearly meeting meant that Iowa Friends were now theoretically independent of other yearly meetings, with the power to compose their own rules without answering to a higher body. In practice, however, Iowa Gurneyites remained tied to other Friends in a system of correspondence and visitation that discouraged significant deviations. And Iowa Friends would initially be content to follow trails that Gurneyite Friends blazed elsewhere. Only in the 1880 s would they themselves begin to set the Quaker agenda. ${ }^{20}$

19. Reminiscences of Nathan T. Frame and Esther G. Frame (Cleveland, 1907), 38; Hamm, Transformation, 37-66. The two other historic "peace churches," the Mennonites and German Baptist Brethren, or Dunkards, experienced similar changes in this period. See Theron F. Schlabach, "The Humble Become 'Aggressive Workers': Mennonites Organize for Mission, 1880-1910," Mennonite Quarterly Review 52 (1978), 91-112; idem, "Mennonites, Revivalism, Modernity -1683-1850," Church History 48 (1979), 398-415; and Albert T. Rank, History of the Brethren Church (Ashland, OH, 1968), 125-67.

20. Jones, Quakers of Iowa, 74-79; Joseph Crosfield to Children, 7 and 16 September 1865, Joseph Crosfield Letters, Library of the Society of Friends, Friends House, London, England. 
By the time of the establishment of the yearly meeting, some Iowa Gurneyites were prepared to carry emulation of other evangelical Protestants in unexpected and radical directions. The first clear signs appeared in the Bangor Meeting in Marshall County. In 1862 two young Friends there broke with tradition by striking up a hymn during a meeting for worship. Although many Friends disapproved, others, including a recorded minister, showed their approbation by joining in. Late in the decade, the meeting found itself troubled by what one called "ranterism," a venerable Quaker pejorative term for any kind of behavior that Friends perceived as disorderly. Apparently, an antidenominational group of the type common in nineteenthcentury America arrived from Indiana and drew some support from local Friends. The "ranters" made "extreme claims" of personal holiness. Horrified Bangor Quakers dismissed the enthusiasts as "insane," but the receptivity of at least some Friends to such teachings shows how open they had become to nonQuakers. In 1867 two ministers, Stacy Bevan from Bangor and John S. Bond from Honey Creek, held a special meeting at Bear Creek in Madison County. By Bevan's account, "the power of the Lord was wonderfully manifested. Many hearts were reached and all broken up, which was followed by sighs and sobs and prayers, confessions and great joys for sins pardoned and burdens rolled off." Older Friends saw this as much too similar to a Methodist revival meeting and tried to stop it immediately with what Bevan called "a strong dose of 'elder tea.'" Afterwards, they strongly admonished the two ministers to return home. Seven years would pass before there was another such outbreak at Bear Creek. ${ }^{21}$

By that time, Iowa Gurneyites had passed through a transformation. As one Iowa Friend wrote, "Changes have come over us in such rapid succession as probably have never been witnessed in any other religious denomination. ${ }^{\prime 22}$ Most of the tradi-

21. E. B. Mendenhall, "When and Where the Revival Flame Was First Kindled," Christian Worker, 15 December 1887, 590-91; "Friends Meetings in Iowa," ibid., 16 June 1884, 417; John Jones Diary, 3 May 1864, typescript, Friends Collection, Earlham College, Richmond, IN; Joel Bean Letter, Friends' Review, 9 July 1870, 731; Darius B. Cook, History of Quaker Divide (Dexter, IA, 1914), 66.

22. J. B., "The English Deputation," Friends' Review, 27 July 1878, 787-88. 
tional peculiarities had been swept away in a wave of revivalism that drew its inspiration from an interdenominational holiness movement.

BEGINNING ABOUT 1870, a new generation of leaders emerged among American Gurneyite Friends. They were relatively young, in their thirties and forties, all recorded ministers. Most came from west of the Appalachians, especially from Ohio and Indiana. These men and women, such as David B. Updegraff, John Henry Douglas, Robert W. Douglas, Esther Frame, Dougan Clark Jr., and Luke Woodard, all shared an intensely evangelical vision of Quakerism, one shaped by their vision of sanctification or holiness. ${ }^{23}$

Between 1860 and 1880 , a powerful holiness movement stirred American Protestantism. Its advocates argued that all Christians should undergo two experiences. The first was conversion, or being born again, in which the believer, by accepting the efficacy of the atoning death of Christ, came into a state of acceptance with God. That should be followed by a second experience of sanctification, in which the power of the Holy Spirit eradicated the propensity to sin. Both experiences were instantaneous, achieved by faith. Many Gurneyite Friends accepted this vision because it had powerful parallels to traditional Quaker doctrine. Friends had long believed in the necessity of holiness. The new movement offered a quicker and, in their view, more scriptural means of accomplishing that. So the bases of a revolution were laid. ${ }^{24}$

23. The following interpretation expands the account found in my Transformation, 77-85. For interpretations of these events that present them as positive developments in Quaker history, see Richard Eugene Wood, "Evangelical Quakers in the Mississippi Valley, 1854-1894" (Ph.D. diss., University of Minnesota, 1985); Carole Spencer, "The American Holiness Movement: Why Did It Captivate Nineteenth-Century Quakers?" Quaker Religious Thought 28 (1998), 19-30; and idem, "Evangelism, Feminism, and Social Reform: The Quaker Woman Minister and the Holiness Revival," Quaker History 80 (1991), 24-48. For an argument that the revival movement was not a break with earlier trends among Gurneyites, see Damon D. Hickey, Sojourners No More: The Quakers in the New South, 1865-1920 (Greensboro, NC, 1997), 35-47.

24. Ibid., 85-95. The literature on the holiness movement in American Protestantism is extensive. See, for example, Timothy L. Smith, Revivalism and Social Reform: American Protestantism on the Eve of the Civil War (New York, 1965); 
Quaker ministers who embraced second-experience holiness found in it an inexorable logic for change. In their experience, evangelical preaching, not silent waiting, brought about such transformation. So they argued that worship should focus on preaching. Moreover, other evangelical Christians, especially Methodists, had proved that the methods of revivalism, such as the use of mourner's benches, singing, and prayer focused on the conversion or sanctification of individuals, were efficacious. So Friends should adopt them. Finally, in the view of Quaker revivalists, traditional Quaker peculiarities, such as plain speech and dress, suggested salvation through works rather than through faith. So they should be discarded. No longer would Friends be a peculiar people, but instead part of the larger community of evangelical holiness believers. The revivalists argued that they never departed "one jot or tittle from the foundation principles ... of the Society of Friends." The converts they made showed that the favor of God rested on their efforts, just as it had rested on the efforts of the early Friends. ${ }^{25}$

This movement, which began in New York, Indiana, and Ohio about 1870, swept through Iowa between 1871 and 1877. Its precise chronology is unclear. In January 1870, Joseph A. Dugdale found that "in some of the meetings of the Orthodox Friends there are those who occasionally break into singing!" As early as 1871, a Friend at Oskaloosa wrote that special meetings were being held there in which Friends were singing and praying for the conversion of individuals and in which "backsliders were renewed." Two years later, the yearly meeting noted that "a reviving spirit has been felt during the past year in our different settlements." In February 1874 John Y. Hoover, a minister from West Branch (and great-uncle of the future president), held a series of meetings at Bear Creek, assisted by ministers from other parts of the yearly meeting. Under the guidance of a quarterly meeting committee, "excitement" and "calls" were absent, but immediately afterwards a full-scale revival broke out, with

Charles Edwin Jones, Perfectionist Persuasion: The Holiness Movement and American Methodism, 1867-1936 (Metuchen, NJ, 1974); and Melvin Easterday Dieter, The Holiness Revival of the Nineteenth Century (Metuchen, NJ, 1980).

25. Proceedings of the Conference of the Society of Friends of America, 1892 (Richmond, IN, 1892), 159; Hamm, Transformation, 77-85. 
the use of both, badly splitting local Friends. Hoover held other such protracted meetings that spring across the state. By the spring of 1875, revival meetings were becoming common across Iowa Yearly Meeting. In the spring of 1876, one Friend worried that the revivals succeeded only "in exciting or scaring some into a kind of professed religion that is not lasting." The revival reached its height in 1877. In that year Benjamin B. Hiatt, leading a revival at Bear Creek, called on all who wished to lead a new life to come to the front seats. About 20 people scrambled forward, some climbing over the benches; Friends who remained at their seats were visited there by others and had prayer groups form around them. Some prayed aloud, some wept, some broke out in anguished testimonies, some sang snatches of hymns. Horrified, more conservative Friends began to move toward the doors of the meetinghouse. As they did, one elderly woman climbed up on a bench and spoke in meeting for the first and only time in her life: "The Society of Friends is dead. This has killed it." ${ }^{26}$

The Bear Creek Friend was not alone in her horror. Across Iowa Yearly Meeting, more conservative Friends found themselves facing a Quakerism that they scarcely recognized. Initially, many had sympathized with the stirrings of new life. Typical was Joel Bean, who, while admitting problems, had asked, "What Reformation has not been accompanied by some excesses? How rare the vigorous growth that needs not the pruning hand." Friends such as Bean abhorred separatism as perpetuating rather than solving problems. But by 1877 other conservative Friends had concluded that there was no hope within the yearly meeting, and so chose separation. ${ }^{27}$

26. Dugdale to Samuel M. Janney, 15 January 1870, box 5, Janney Papers; Cook, Memoirs of Quaker Divide, 68; Lizzie D. Presnall to Susie Janeway, 2 July 1871, box 1, Samuel E. Haworth Papers, Friends Historical Collection, Guilford College, Greensboro, NC; Zenas L. Martin to Janeway, 14 May 1876, ibid.; Philemon Jones, "Iowa Yearly Meeting," Christian Worker, 15 April 1875, 123; "The Church at Work," ibid., 15 January 1874, 22; J. Y. Hoover Letter, Friends' Review, 2 January 1875, 313-14; "Iowa Yearly Meeting," ibid., 9 October 1875, 123; Hamm, Transformation, 84-85; Hoover, History, 129; Iowa Yearly Meeting, Minutes, 1873, 20; Hulda Hoover McLean, Genealogy of the Herbert Hoover Family (Palo Alto, CA, 1967), 320-21.

27. Hamm, "Joel Bean and the Revival in Iowa," 33, 43. 
The process began at Bear Creek in May 1877, when conservatives there called a conference to consider "the present and sorrowful condition of our beloved and once favored society." They drew up a list of particulars that they found objectionable. Some Friends, they concluded, had eschewed "the spirituality of the Gospel" in favor of "a literal knowledge" of the Bible. They had given up the necessity of the long, tried gradual attainment of holiness and instead wanted to make religion "easy to the flesh" and amenable to "the friendship, the honor, and the fashions of the world." They showed "an untempered zeal by taking up one particular truth" - sanctification- "to the exclusion of other important truths." They dismissed "the writings of ancient Friends," particularly in regard to the Inner Light. They had brought into meetings for worship "much formality in the way of reading and singing," which, while making pretensions of godliness, were "the product of intellect and imagination, rather than proceeding from the immediate inspiration of the true Shepherd." Finally, they objected to the conduct of the revival meetings: "the disorder, confusion, and the exciting scenes attending many of them, wherein the young and inexperienced are urged to give expression to their over-wrought feelings in a manner inconsistent with our principles." On this basis, those present agreed that the time had come to replace the leaders who had allowed such declension in favor of Friends sound in historic faith. ${ }^{28}$

Over the next three months, conservatives in the monthly meetings of Bear Creek, Summit Grove, and North Branch organized separately, culminating in the formation of what they claimed was the true Bear Creek Quarterly Meeting. Thus when Iowa Yearly Meeting assembled in September, it faced two competing delegations, each claiming to represent Bear Creek Quarterly Meeting. Not surprisingly, the yearly meeting decided in favor of the revivalists. In response, the Bear Creek conservatives departed and on September 7 formed what they called Iowa Yearly Meeting of Conservative Friends.

Over the next few years, similar separations took place in other parts of the yearly meeting, most significantly at Salem

28. Jones, Quakers of Iowa, 166-70; "An Action of a Conference of Friends," Friend, 30 June 1877, 365-66. 
and West Branch. A revival in West Branch in early 1880 led by Ohio minister David B. Updegraff, the most aggressive of all holiness Friends, split Friends in the area, although the conservatives did not formally separate until 1883 . It also marked the final alienation of Joel Bean, who had for years served as clerk of the yearly meeting but was by now hostile to the departures from tradition he saw taking place around him. In March 1881 Bean published a biting attack titled "The Issue." Bean acknowledged that the revival had claimed impressive results, but argued that they were largely superficial. Instead, "disorganization and disintegration are confessedly making rapid progress," he wrote, "and most rapid where protest is silenced and conservatism most inert." In September Bean made one last attempt to try to move the yearly meeting away from revival control. He failed, and within a year had given up the struggle to move to San Jose, California. ${ }^{29}$

BEAN left behind an Iowa Yearly Meeting that would, in the remaining years of the century, earn a paradoxical reputation. On one hand, it took the lead in bringing change to American Friends, particularly the introduction of the pastoral system. On the other, Iowa Yearly Meeting also made itself a center of controversy through what many Friends elsewhere saw as its intolerance of any departure from revivalist orthodoxy, even when the departure was thoroughly grounded in historic Quaker writings and beliefs.

One of the fruits of the revival was the influx of large numbers of new converts. In some cases, these were Friends who had lost their membership earlier and now took advantage of the relaxation of the Discipline to join again. In other cases, the new members had no previous connection with Friends. Membership statistics show a growth from about 7,600 members in 1866 to more than 11,000 in 1890 . Revivalists after 1875 began to appoint meetings in areas where no Friends lived. The result was the formation of new congregations. The combination of Quaker migration and aggressive revivalism meant that by 1885

29. Hamm, "Joel Bean and the Revival in Iowa," 44-46; Joel Bean, "The Issue," British Friend, 1 March 1881, 49-51; Jones, Quakers of Iowa, 171-74. 
Iowa Yearly Meeting was the most geographically dispersed in the world, taking in meetings in ten states from Louisiana to Minnesota and from Iowa to the Pacific Coast. ${ }^{30}$

The problem, especially in the case of new converts, was pastoral care. Once the revivalists had departed, these new Friends often found themselves in meetings that were largely silent, with no one taking particular responsibility for nurturing new members. Even those from Quaker backgrounds, once they had experienced the fire of the revival and sanctification, felt the need for regular preaching. Sometimes resident recorded ministers met the need, but there was no guarantee that every meeting would have such a minister. As early as 1877 the yearly meeting had heard calls for "a more even distribution" of ministers and had discussed the creation of a fund to support ministers who wished to engage in religious work full time. This problem was not unique to Iowa, but Iowa's solution would be the most radical. $^{31}$

By 1886, Iowa Yearly Meeting required each of its meetings to appoint one minister as its pastor, providing a salary or some other form of support. When local meetings could not afford one, then the yearly meeting evangelistic committee would try to help. John Henry Douglas, a leading revival minister who had worked extensively in Iowa, was hired to serve as the yearly meeting's superintendent and charged with overseeing the development of the system. Friends elsewhere had experimented with pastors as early as a decade before, but Iowa was the first yearly meeting to endorse the system formally. ${ }^{32}$

The pastoral system was a departure from Quaker tradition, which had long opposed what it scornfully called "hireling ministers." Iowa Friends justified it, however, as both necessary and scriptural. "The Lord has appointed the preaching of the word

30. Editorial, Friends' Review, 6 April 1872, 524; "Society Intelligence," ibid., 22 October 1891, 198; "A Lesson in Figures," American Friend, 24 April 1902, 385.

31. Hamm, Transformation, 124-30; B. F. Trueblood, "Iowa Yearly Meeting and the Pastorate," Christian Worker, 11 September 1890, 579; "Iowa Yearly Meeting," ibid., 15 February 1877, 98; David Hunt, "The Church and the Preached Gospel," ibid., 27 December 1883, 750-52; Henry Stanley Newman, Memories of Stanley Newman (New York, 1883), 238.

32. Iowa Yearly Meeting, Minutes, 1886, 13-14; Hamm, Transformation, 127. 
for the conversion of sinners and the edification of His church, and this of itself is a sufficient reason why the Yearly Meeting should desire that all meetings under its care should have the benefit of this divinely appointed means of growth and power," it explained in a statement issued to justify the new policy. They did not intend "that a single person should be placed at the head of a meeting and do all the preaching, nor that there should necessarily be preaching in every single instance." But they were convinced that satisfying the hunger of members for regular Gospel preaching and maintaining the momentum of the revival of the 1870 s required a provision for regular ministry. ${ }^{33}$

Iowa Friends argued that they were not abandoning traditional Quaker commitments to the right of all to speak in meeting. Nor did the policy represent any compromise with a "hireling ministry." Ministers were not priests - they acquired no special unction from the act of recording. They would not use titles such as "Reverend," nor would Friends be divided into "clergy" and "laity." Any suggestion of "preaching for money" was dismissed with reference to the meager support that pastors actually received. Henry Stanley Newman, an English Friend who visited Iowa in 1889, offered as typical Ezra Pearson, the pastor of Hesper Meeting. For acting as pastor at Hesper and other nearby meetings, Pearson received the use of a small house rent-free, with a salary of $\$ 200$ per year, much of it paid in kind. In 1890 the average annual salary for a pastor in the yearly meeting was $\$ 136$, less than the wages of an unskilled factory worker. By 1888 , the superintendent of the Iowa Yearly Meeting was claiming unqualified acceptance of the system, telling a skeptical Philadelphia Friend that every meeting in Iowa desired a pastor. ${ }^{34}$

Still, such a step was certain to be controversial, both in and outside of Iowa. Criticisms varied. John F. Hanson, an Iowa Friend sympathetic to revivalism, worried about what would

33. Iowa Yearly Meeting, Minutes, 1886, 13.

34. H. S. Newman, "How a Pastor in the Friends' Church Lives in Iowa," Christian Worker, 12 December 1889, 788-89; "Ministers and Pastors in Iowa," ibid., 23 September 1886, 450; John Henry Douglas Letter, Friends' Review, 8 November 1888, 237; Editorial, ibid., 9 October 1890, 168; J. H. Douglas to Henry Hartshorne, 10 February 1887, 12 November 1888, box 10, Hartshorne Family Papers, Quaker Collection, Haverford College, Haverford, PA. 
happen in meetings with more than one minister if one was appointed pastor. Would the gifts of the others be lost? Another member of the yearly meeting, J. H. Stuart, argued that the great growth of the 1870 s took place without pastors, so they were unnecessary. Such radical change, he claimed, would lower the standard of spirituality and "would surely lead to a hurtful class distinction as between the ministers and the laity." Still others worried that pastors would dictate to their members. Outside the yearly meeting, negative reactions were even stronger. Henry Hartshorne, the editor of the Philadelphia Friends' Review, bluntly told Douglas that pastoral meetings would no longer be Friends meetings. Many members of the London Yearly Meeting strongly objected, questioning likewise whether Iowa Yearly Meeting was still a body of Friends. By 1895, Richard H. Thomas, a leading Friend in Baltimore, concluded that the pastoral system had effectively destroyed real Quakerism in Iowa Yearly Meeting. But the critics could not hold back the system's advance. By 1900, a majority of American Friends were members of pastoral meetings. ${ }^{35}$

THE MOVEMENT toward the pastoral system was in some respects a reaction to fear-fear that without pastoral care members and converts would be lost. But Iowa Yearly Meeting knew other fears in these years, fears that many other evangelical Protestants shared in the 1880 s and 1890 s. Social change and the growing influence of critical scholarly study of the Bible convinced many that the very foundations of Christian faith were under assault. In response, one pastor in the Iowa Yearly Meeting argued, "Only on the basis of correct doctrine can any one hope to enter into the fullest possession of the riches of grace." For some, this attitude became a ferocious anti-intellectualism.

35. Richard H. Thomas to Rufus M. Jones, 13 December 1895, box 1, Rufus M. Jones Papers, Quaker Collection; Hartshorne to Douglas, 17 November 1888, box 4, Hartshorne Papers; J. H. Stewart [sic], "Some Phases of the 'Pastoral' Question," Christian Worker, 30 September 1886, 458; John F. Hanson, "A Question Concerning Ministers," ibid., 27 December 1888, 615; "Iowa in London Yearly Meeting 1888," ibid., 16 August 1888, 386-88; "Discussion about Iowa Yearly Meeting," ibid., 22 November 1888, 560; J. H. Stuart, "Some Phases of the Pastoral Question," Friends' Review, 4 November 1886, 212. 
"We'll get the pure Gospel today, because this Friend can't read," one visitor to Iowa Yearly Meeting heard. Many pastors and leaders inveighed against the growth of "unsoundness." Not just fraternal lodges, theaters, dancing, "and all other kinds of unholy amusements" came in for criticism, but even Christmas trees and football games. The cautious links to Hicksite Friends that had appeared in the 1860 s now disappeared, as revivalists dismissed Hicksites as "entangled in unbelief." ${ }^{36}$

These fears would also give rise to what would become probably the most notorious heresy case in American Quaker history. In many denominations, colleges and seminaries were the focus of such fears. But Friends had no theological seminaries, and Penn College in Oskaloosa, which the yearly meeting controlled, was before 1900 a bastion of holiness orthodoxy. In 1888 , for example, the yearly meeting proudly noted that only three in the entire student body had not been converted. Instead, the focus of Iowa's fears in the 1880s and 1890s would be the yearly meeting's former clerk, Joel Bean. ${ }^{37}$

Early in 1882, Joel and Hannah Bean had left Iowa for San Jose, California. Declining health pulled them toward a warmer climate, and Joel simply wanted to escape the theological battles in the yearly meeting. The Friends meeting in San Jose was, however, part of Iowa Yearly Meeting. In 1885, after it had resisted the efforts of revivalist ministers, Honey Creek Quarterly Meeting pronounced San Jose's leaders unsound in Christian faith and "laid down" the monthly meeting there, attaching its members to Honey Creek Monthly Meeting, nearly two thousand miles away in Hardin County, Iowa. As the revival party acquired strength in San Jose, the Beans and their sympathizers

36. John Henry Douglas, "Evangelistic Work in America," Friends' Review, 30 August 1884, 52-53; "From the Field," Christian Worker, 31 January 1889, 70; "A Question about Iowa Yearly Meeting," ibid., 29 November 1888, 570; Pliny Fry, "Correct Teaching," ibid., 10 May 1888, 221; "Iowa Yearly Meeting," American Friend, 20 September 1894, 231; ibid., 26 April 1900, 399; J. Y. Hoover, "What Is Truth?" ibid., 10 April 1902, 346; Edgar P. Ellyson, "Why I Am Opposed to Church Amusements," ibid., 10 January 1895, 41; J. Y. Hoover, "A Football Team or Pugilism, Which?" Evangelical Friend, 25 January 1906, 53.

37. "Iowa Yearly Meeting," Friends' Review, 27 September 1888, 134; Jacob Baker, Incidents of My Life and Work of 84 Years (Richmond, IN, 1911), 173-74. 


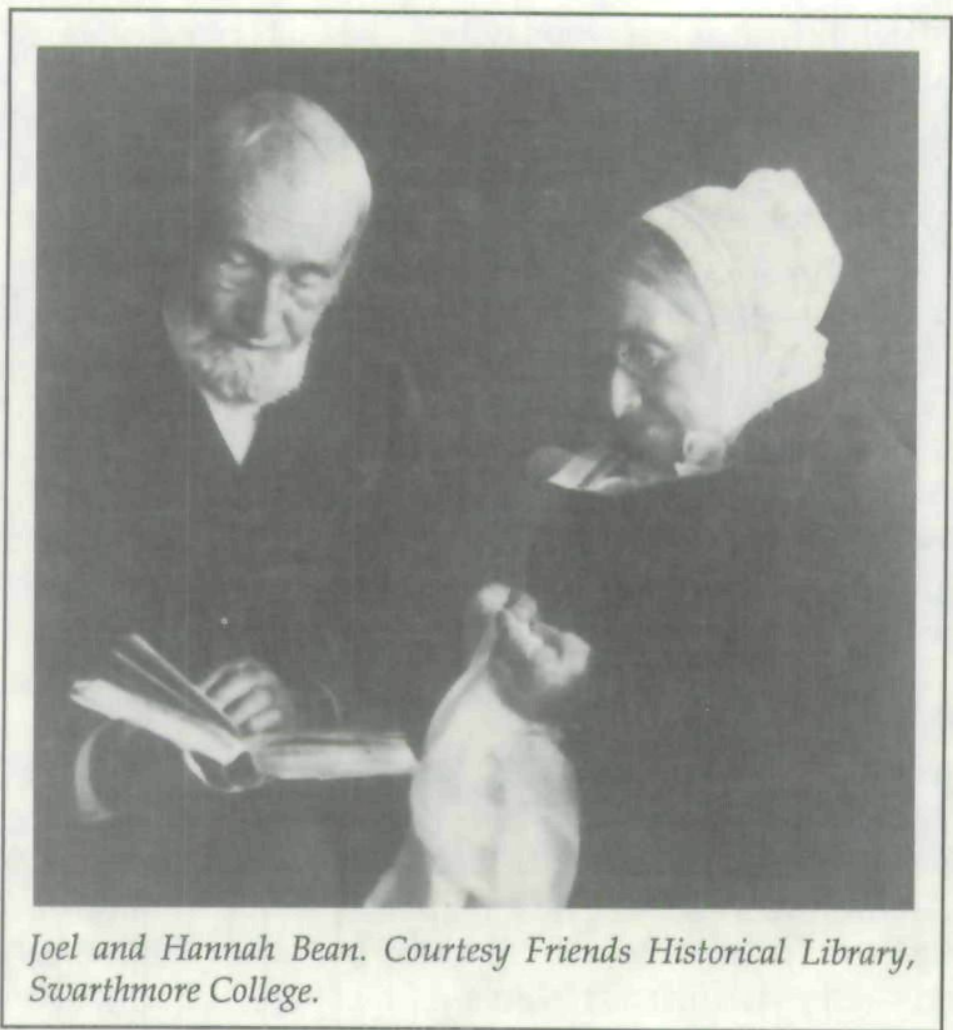

built a small meetinghouse in College Park, where they worshiped in traditional ways. ${ }^{38}$

The final controversy came in 1893 . Two years earlier, the yearly meeting had adopted a set of nine questions that all ministers and elders were required to answer affirmatively, as a guard against "unsoundness." The questions involved the nature of God and the Holy Spirit, the deity of Christ, the Atonement, and the authority of Scripture, along with the Resurrection and eternal punishment of the wicked. Early in 1893, Honey Creek Quarterly Meeting of Ministry and Oversight, seeking to bring the conflict between the College Park group and the rest of the yearly meeting to an end, offered to end all proceedings if the Beans would give unequivocal affirmative

38. David C. Le Shana, Quakers in California: The Effects of 19th Century Revivalism on Western Quakerism (Newberg, OR, 1969), 88-95. 
answers to each of the questions and make a general statement of unity with the yearly meeting. Joel and Hannah Bean did so, with two qualifications. In one, they noted their reservations about the pastoral system, saying that English Friends spoke for them on the subject. As for eternal punishment, they could not commit themselves to any statement that "any individual soul is condemned to endless punishment until the resources of God's infinite compassion and the means of His redeeming grace and power in Christ Jesus for their salvation have been exhausted." Because of his uncertainty on the subject, Joel explained, he had never spoken publicly about it. Here Honey Creek Friends scented "unsoundness," and asked for an explanation. When the Beans supplied it, the Honey Creek Friends pronounced it unsatisfactory and deposed the Beans as recorded ministers. ${ }^{39}$

Honey Creek's action aroused a fire storm of controversy. The Beans were well known in both North America and Great Britain, with numerous admirers. Although some might disagree with Joel on the subject of eternal punishment, his opinion was private, divulged only on request. It was one thing to proclaim an unorthodox view publicly, quite another to ponder it privately. In this case, supporters of the Beans saw an "evident lack of true charity and brotherly kindness" and complained that the couple were victims of "narrow-minded, ... ignorant, self sufficient dabsters in theology." Reactions in London Yearly Meeting were even stronger. The Beans' supporters there blasted the proceedings as "inquisitorial," the natural fruit of the pastoral system and other enthusiasms of Iowa Yearly Meeting. Hundreds signed a public letter announcing that they still regarded the Beans as divinely called ministers. The Bean case, in fact, would be a turning point in souring English Friends generally on American pastoral Quakerism. ${ }^{40}$

39. The entire correspondence between the Beans and Honey Creek Friends is reprinted in "Joel Bean," Friends' Review, 12 October 1893, 186-87. For the questions for ministers and elders, see Iowa Yearly Meeting of Friends, Book of Discipline (Oskaloosa, 1891), 111-14.

40. "The American Declaration of Faith: A Result," British Friend, November 1893, 305-7; Hamm, Transformation, 142. The English Friends' letter was printed and circulated as a broadside. A copy is in box 4, Jones Papers. 
AS THE TWENTIETH CENTURY BEGAN, Iowa Quakers spanned almost the entire spectrum of American Protestantism. One observer thought them as different from each other as Protestants and Catholics. A small part, the Hicksite Friends, were part of a persuasion comfortable with the growing liberal movement within American Protestantism. But in Iowa, Hicksites were relatively few and declining in numbers. More numerous were Conservative Friends, determined to resist any change in historic Quaker belief. They were also relatively few, however, and were divided among themselves by older governmental and doctrinal splits. Not until 1918 did the Wilburite Friends affiliated with Ohio Yearly Meeting finally transfer their allegiance and join Iowa Yearly Meeting of Conservative Friends. ${ }^{41}$

Most numerous were the Gurneyite Friends who made up the larger Iowa Yearly Meeting. They had experienced considerable growth since the Civil War, even while giving birth to new yearly meetings in Oregon and California. But that growth was the fruit of dramatic, fundamental changes. Critics dismissed the Gurneyites as not knowing what real Quakerism was. Even those who accepted the changes worried about the future. Writing in the early years of the century, historian Louis T. Jones thought that there was little difference between the "Friends Church" in Iowa and other Protestant denominations. The brief periods of silence in worship were regarded by many as a waste of time; in most congregations, the minister controlled all aspects of the service. Such critics questioned what justified the existence of pastoral Friends as a separate denomination, a question that would continue to stir controversy among Iowa Friends over the course of the twentieth century. ${ }^{42}$

41. Jones, Quakers of Iowa, 150-52, 159; William P. Taber Jr., The Eye of Faith: A History of Ohio Yearly Meeting, Conservative (Barnesville, OH, 1985), 131-32.

42. Jones, Quakers of Iowa, 95, 110-11, 127-29; Minerva Harvey to Joel and Hannah E. Bean, 2 March 1903, box 4, Bean Papers. 
Copyright of Annals of Iowa is the property of State of Iowa, by \& through the State Historical Society of Iowa and its content may not be copied or emailed to multiple sites or posted to a listserv without the copyright holder's express written permission. However, users may print, download, or email articles for individual use. 